\title{
Can macrophytes be useful in biomanipulation of lakes? The Lake Zwemlust example
}

Teresa Ozimek, Ramesh D. Gulati' \& Ellen van Donk ${ }^{2}$

Department of Hydrobiology, Institute of Zoology, University of Warsaw, Nowy Swiat 67, 00-046 Warsaw, Poland; ' Correspondence addres: Limnological Institute, 'Vijverhof' Laboratory, Rijksstraatweg 6, 3631 AC Nieuwersluis, The Netherlands; ${ }^{2}$ Provincial Waterboard of Utrecht, Postbox 80300, 3508 TH Utrecht, The Netherlands

Key words: lake biomanipulation, submerged macrophytes, filamentous green algae, phosphorus and nitrogen cycling

\begin{abstract}
Lake Zwemlust (area $1.5 \mathrm{ha}, \mathrm{Z}_{\mathrm{m}} 1.5 \mathrm{~m}$ ) has been the object of an extensive limnological study since its biomanipulation involving removal of planktivorous fish (bream) in March 1987 and emptying of the lake. In the subsequent summer period of 1987 the Secchi depth increased to the lake bottom $(2.5 \mathrm{~m})$, compared with $\mathrm{ca} 30 \mathrm{~cm}$ in the earlier summers. The reaction of submerged macrophytes to improving under-water light climate was rapid. In summer 1987, besides the introduced Chara globularis, 5 species of submerged macrophytes occurred and colonized $10 \%$ of the lake area. In 1988 and 1989 only quantitative changes were observed; new species did not appear, but the area colonized by macrophytes increased by 7 and 10 times, respectively. Elodea nuttallii was dominant among the macrophytes and Mougeotia sp. among the filamentous green algae. Their abundance, contributed to transient N-limination of phytoplankton causing a persistent clear water phase in 1988 and 1989, unlike in 1987 when zooplankton grazing contributed chiefly to the water clarity. Laboratory bioassays on macrophytes confirmed nitrogen limitation.
\end{abstract}

\section{Introduction}

With increase of lake trophy, the area occupied by and biomass of submerged macrophytes decreases (Phillips et al., 1978; Ozimek \& Kowalczewski, 1984; Lachavanne, 1985); so in hypertrophic lakes plant vegetation is scarce or absent. Phillips et al. (1978) suggested that in shallow lakes the main cause of decline of macrophytes is shading by epiphytes, loosely connected filamentous algae and subsequent development of high phytoplankton concentrations. The multiple role of macrophytes in functioning of shallow lake ecosystems is well documented (e.g. Boyd, 1971;
Pieczynska \& Ozimek, 1976; Carpenter \& Lodge, 1986; Engel, 1988). Disappearance of macrophytes causes, directly or indirectly, changes in other communities in lakes. So, restoration of shallow, hypertrophic lakes should be very closely connected with restoration of water plants (Moss, submitted).

We studied changes in submerged macrophytes in a shallow hypertrophic Lake Zwemlust (The Netherlands) in a two-year period (1988-'89) after its restoration by biomanipulation in spring 1987. The lake has been the object of extensive limnological studies since its biomanipulation involving removal of planktivorous fish (bream) 
in March 1987 (Van Donk et al., 1989). During this operation the lake was emptied by pumping out water and its fish was simultaneously removed. The lake got refilled within a week chiefly by nutrient seepage water from the River Vecht. Before biomanipulation macrophytes were absent. During the biomanipulation operation Nuphar lutea L. and Clara globularis Thuill. were introduced to the lake as refuges for pike.

In this paper we examine the changes after biomanipulation in composition and in relative abundance of the total biomass of macrophytes, and present data on growth and nutrient uptake rates of Elodea nuttalli, the most important among the macrophyte species present in the lake. Also, bioassay experiments were carried out on Elodea sp. in the summer of 1988 when $\mathrm{N}-\mathrm{NO}_{3}$ and $\mathrm{N}-\mathrm{NH}_{4}$ concentrations had declined to near detection levels but $\mathrm{P}_{-} \mathrm{PO}_{4}$ level was high and still close to the pre-biomanipulation level of $c a: 1 \mathrm{mg}$ $\mathrm{P}^{-1}$ (Van Donk et al., 1989).

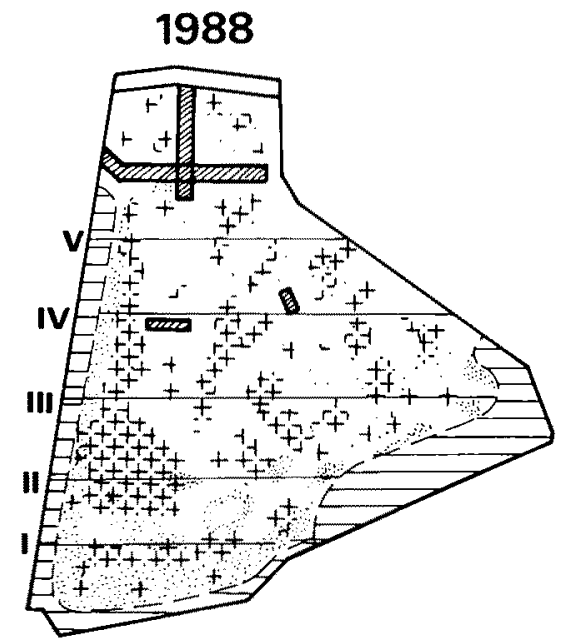

\section{Material and methods}

\section{Field studies}

Lake Zwemlust (area, 1.5 ha; mean depth $1.5 \mathrm{~m}$, maximum depth $2.5 \mathrm{~m}$ ) is located in the Province of Utrecht, The Netherlands. It is used for recreative purposes with 100-300 visitors daily in summer, but there may be a tenfold increase in numbers on warm days.

The lake was sampled three times during August-November in 1988 and once in July 1989. Samples were collected from 5 transects (Fig. 1); in total 50 samples were collected on each sampling date. A modified Bernatowicz type sampler (sampling area, $0.1 \mathrm{~m}^{2}$ ) was used to collect samples to study species composition and biomass of macrophytes and macro-algae. Macrophytes were segregated into species and periphyton and calcium deposits were removed by washing; the dry weight, nitrogen and phosphorus contents were measured. The nitrogen content of the plants was determined using a $\mathrm{CHN}$ analyzer (Perkin-Elmer 240). Phosphorus was determined with a molybdate method according to Golterman (1969). Filamentous green algae

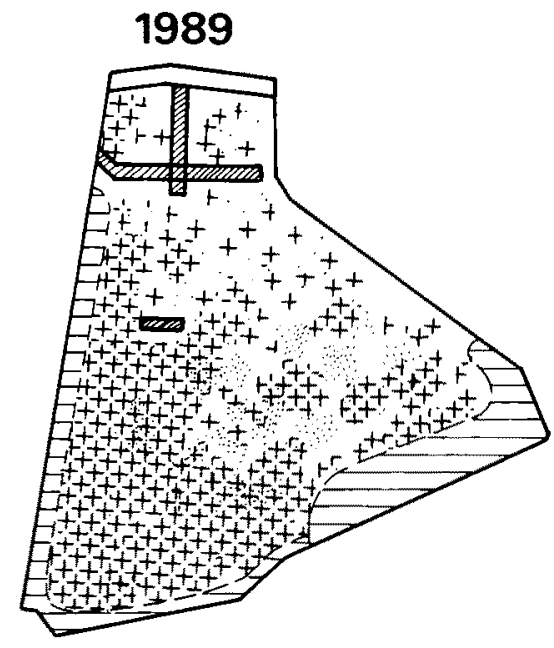

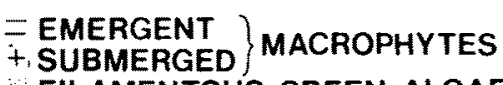 \\ FILAMENTOUS GREEN ALGAE}

Fig. I. Schematic distribution of submerged macrophytes and filamentous green algae in Lake Zwemlust in August 1988 and July 1989. 
floating on water surface, and farming a scum-like material, were collected from a quadrat of $100 \mathrm{~cm}^{2} ; 20$ samples were collected each time.

\section{Bioassay experiments}

The growth rate and $\mathrm{N}$ and $\mathrm{P}$ uptake rates were determined in water enriched with $\mathrm{N}$ and $\mathrm{P}$ levels comparable with those measured in Lake Zwemlust directly after biomanipulation in 1987. The biomass per unit area of Elodea nuttallii used in such experiments was similar to the mean biomass $\mathrm{m}^{-2}$ noted in Lake Zwemlust in summer 1988.

Plants and water for the experiments were collected from the lake in September 1988. The plants were washed under running tap water, taking care not to damage the plant tissues. Before the experiment the apical portion $(\mathrm{ca} 20 \mathrm{~cm}$ ) of the mother shoot was cut off and acclimatized 3 days in the laboratory at $19^{\circ} \mathrm{C}, 16: 8$ light : dark cycle, and at light intensity (PhAR) of about $30 \mathrm{~W} \mathrm{~m}^{-2}$. Several samples of plants were weighed fresh after blotting out the surface moisture, dried at $105^{\circ} \mathrm{C}$ for $24 \mathrm{~h}$ and then weighed again, to get the fresh weight and dry weight, respectively.

The biomass increase of $E$. nuttallii was studied at different nitrogen levels. Five shoots were cultivated in four sets (I-IV) of two-litre aquaria using: one-litre filtered (Whatman $\mathrm{GF} / \mathrm{F}$ ) water from Lake $Z$ wemlust (I), filtered water $+2 \mathrm{mg}$ $\mathrm{N}-\mathrm{NO}_{3}$ (II), filtered water $+2 \mathrm{mg} \mathrm{N}-\mathrm{NH}_{4}$ (III), and filtered water $+2 \mathrm{mg} \mathrm{N}-\mathrm{NO}_{3}+2 \mathrm{mg} \mathrm{N}-\mathrm{NO}_{4}$ (IV). The experiment lasted 14 days. At the beginning and end of experiment total dry weight of the plant material and concentrations of $\mathrm{N}-\mathrm{NH}_{4}, \mathrm{~N}-\mathrm{NO}_{3}$ and $\mathrm{P}-\mathrm{PO}_{4}$ in each aquarium were measured. Each treatment was replicated five times. Uptake rates of $\mathrm{N}-\mathrm{NH}_{4}, \mathrm{~N}-\mathrm{NO}_{3}$, and $\mathrm{P}_{-} \mathrm{PO}_{4}$ were also measured at different levels of nitrogen.

To determine temporal changes in nutrient concentration due to uptake, Elodea nuttallii ( $0.5 \mathrm{~g}$ dry weight) was cultivated in 11 filtered lake water with $2 \mathrm{mg} \mathrm{l}^{-1}$ each of N-NH${ }_{4}$ and N-NO . Phosphorus and nitrogen concentrations were meas- ured after 4, 8, 16, 32 and $64 \mathrm{~h}$. For each exposure period 3 aquaria with plants and 3 blanks were used. The experiment was carried out in laboratory conditions described above. $\mathrm{P}_{-} \mathrm{PO}_{4}$ was determined according to Murphy \& Riley (1962), $\mathrm{N}-\mathrm{NO}_{3}$ according to Stainton et al. (1974) and $\mathrm{N}-\mathrm{NH}_{4}$ following Verdouw et al. (1977). For all determinations a Cerco automated analyzer was used.

\section{Results}

Distribution, biomass, nitrogen and phosphorus accumulation

In the summer of 1988 macrophytes and filamentous green algae occupied $c a$ one ha, i.e. about $70 \%$ of lake bottom; in summer of 1989 almost $100 \%$ of the lake bottom was covered. The distribution of macrophytes and filamentous green algae is shown schematically in Fig. 1. Six species of aquatic vascular plants, Chara globularis and 9 taxa of filamentous algae were present in both 1988 and 1989 (Table 1). Among the macrophytes $E$. nuttallii attained the highest frequency (Table 1) and among the algae, Mougeotia (August-November 1988) and Cladophora (July 1989). C. globularis was introduced into the lake during biomanipulation operation, the rest of submerged macrophytes occurred naturally in the lake. The highest macrophyte biomass observed during the study namely, $\mathrm{ca} 120 \mathrm{~g}$ dry weight $\mathrm{m}^{-2}$ for the whole lake area, was in September-October 1988 (Fig. 2) and algal maximum, ca $13 \mathrm{~g}$ dry weight $\mathrm{m}^{-2}$, occurred in August-September 1988 (Fig. 3). The standing crop maxima of macrophytes and algae during the investigation period were: $1255.8 \mathrm{~kg} \mathrm{DW}$ and $144.0 \mathrm{~kg} \mathrm{DW}$, respectively. In July 1989, macrophyte and algal standing crops on areal basis of 320 and $c a 25 \mathrm{~g} \mathrm{DW}$ $\mathrm{m}^{-2}$, respectively, were three and two times higher than in the summer months of 1988 (Figs. 2 and 3 ).

E. nuttallii was dominant in both the years: it contributed $\mathrm{ca} 70 \%$ to the total macrophytes biomass in 1988 and $82 \%$ in 1989. In 1988 it 
Table 1. Frequency of occurrence and contribution to biomass of the submerged macrophytes in Lake Zwemlust, in August 1988 and July 1989.

\begin{tabular}{|c|c|c|c|c|}
\hline \multirow[t]{2}{*}{ Species } & \multicolumn{2}{|c|}{ Frequency $(\%)$} & \multicolumn{2}{|c|}{ Contribution to biomass $(\%)$} \\
\hline & 1988 & 1989 & 1988 & 1989 \\
\hline Elodea muttallii (Planch.) St. John & 54.7 & 100.0 & 72.0 & 82.4 \\
\hline Ceratophyllum demersum $\mathrm{L}$. & 52.8 & 63.0 & 2.0 & 5.9 \\
\hline Chara globularis Thuill. & 47.2 & 55.6 & 20.0 & 8.7 \\
\hline Elodea canadensis Michx. & 37.7 & 22.2 & 4.0 & 2.3 \\
\hline Potamogeton bertholdii L. & 24.5 & 29.6 & 1.0 & 0.5 \\
\hline Potamogeton crispus $\mathbf{L}$. & 24.5 & 7.4 & 0.7 & 0.1 \\
\hline Potamogeton acutifolius $\mathrm{L}$. & 11.3 & 3.7 & 0.3 & 0.1 \\
\hline
\end{tabular}

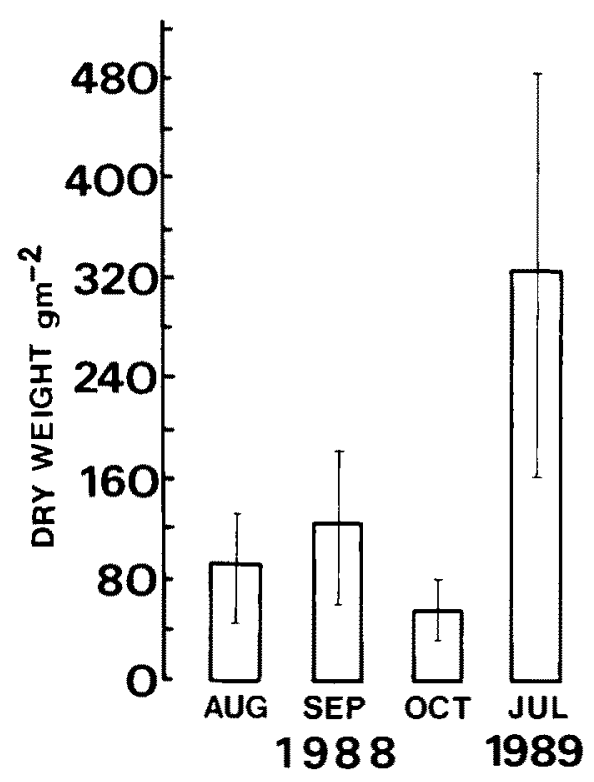

Fig. 2. Average dry weight ( $95 \%$ confidence limits) of submerged macrophytes in Lake Zwemlust.

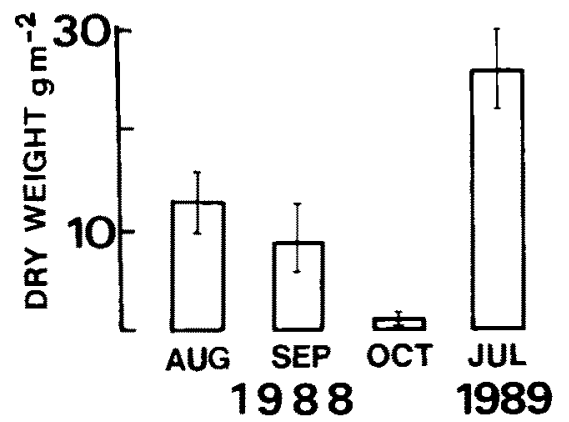

Fig. 3. Average dry weight ( $95 \%$ confidence limits) of filamentous green algae in Lake Zwemlust. occurred in clumps growing from the bottom to water surface with shoots ca $2 \mathrm{~m}$ long; also smaller shoots $(20-40 \mathrm{~cm})$ grew on the bottom and non-rooted, floating shoots were present. The biomass of $E$. nuttallii ranged from $0.1 \mathrm{~g} \mathrm{DW} \mathrm{m}^{-2}$ for the floating shoots to $c a 500 \mathrm{~g} \mathrm{DW} \mathrm{m}^{-2}$ for the clumps. The clumps occupied $<5 \%$ of lake surface in 1988 , but $>30 \%$ in 1989. E. nuttallii is evergreen, it spends winter as dormant species. In 1988 the plant started to produce many dormant apices already in October and the old shoots started decaying. In early November the dormant apices contributed $\mathrm{ca} 23 \%$ to the biomass. In December the old shoots were noted only sporadically (R. Kornijow, pers. communication).

The macrophytes and algae accumulated substantial amounts of $\mathrm{N}$ and $\mathrm{P}$ (Table 2). The differences in the accumulated contents of $\mathrm{N}$ and $\mathrm{P}$ by macrophytes and algae resulted from large differences observed in their biomasses, since $\mathrm{N}$ and $P$ contents per unit dry weight in macrophytes and algae differed only slightly (unpublished data). In winter, about one-third of the total $\mathrm{P}$ and $\mathrm{N}$ in the plants was stored in dormant apices (Table 3).

\section{Bioassay experiments}

The biomass increments of $E$. nuttallii were from 2 to 4 times greater than $\mathrm{N}$-enriched $\left(2 \mathrm{mg} \mathrm{l}^{-1}\right.$ each of $\mathrm{N}-\mathrm{NH}_{4}$ and $\mathrm{N}-\mathrm{NO}_{3}$ ) water than in the controls (Fig. 4); the differences between treatments II, III and IV and the control if compared as final dry weights were significant (Mann- 
Table 2. Accumulation of nitrogen and phosphorus in macrophytes and in filamentous green algae in Lake Zwemlust, 31 August-2 November 1988.

\begin{tabular}{|c|c|c|c|c|c|}
\hline \multirow[t]{2}{*}{ Plant } & \multirow[t]{2}{*}{ Period } & \multicolumn{2}{|c|}{ Nitrogen } & \multicolumn{2}{|c|}{ Phosphorous } \\
\hline & & $\mathrm{g} \mathrm{m}^{-2}$ & total $\mathrm{kg}$ & $\mathrm{g} \mathrm{m}^{-2}$ & total $\mathrm{kg}$ \\
\hline \multirow[t]{3}{*}{ Macrophytes } & Aug-Sep & 2.3 & 24.1 & 0.6 & 6.6 \\
\hline & Sep-Oct & 3.0 & 31.2 & 0.9 & 9.5 \\
\hline & Oct-Nov & 2.1 & 15.8 & 0.6 & 4.2 \\
\hline \multirow[t]{3}{*}{ Algae } & Aug-Sep & 0.4 & 4.1 & 0.09 & 0.9 \\
\hline & Sep-Oct & 0.2 & 2.1 & 0.04 & 0.4 \\
\hline & Oct-Nov & 0.6 & 0.4 & 0.01 & 0.1 \\
\hline
\end{tabular}

Table 3. Accumulation of nitrogen and phosphorus in old summer shoots and in new winter shoots of $E$. nuttallii in Lake Zwemlust, November 1988.

\begin{tabular}{|c|c|c|c|c|c|}
\hline \multirow[t]{2}{*}{ Shoots } & \multirow{2}{*}{$\begin{array}{l}\text { Dry weight } \\
\mathrm{g} \mathrm{m}^{-2}\end{array}$} & \multicolumn{2}{|l|}{$N$} & \multicolumn{2}{|l|}{$P$} \\
\hline & & $\%$ D.W. & $\mathrm{g} \mathrm{m}^{-2}$ & $\%$ D.W. & $\mathrm{g} \mathrm{m}^{-2}$ \\
\hline Old summer & 31.3 & 3.7 & 1.2 & 0.9 & 0.3 \\
\hline New winter & 9.4 & 4.7 & 0.4 & 1.3 & 0.1 \\
\hline
\end{tabular}

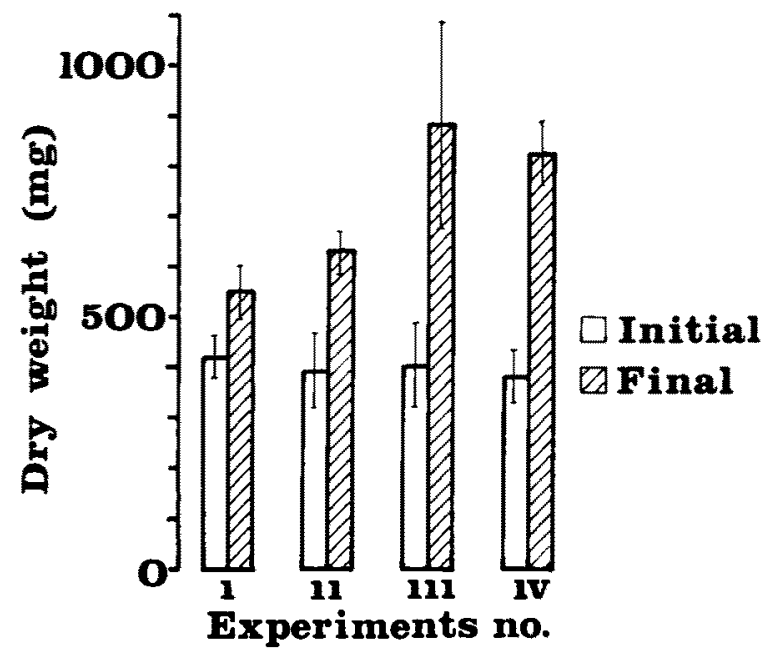

Fig. 4. Changes of dry weight $f$ E. nuttallii under different nitrogen enrichment levels: I, blank; II, water from Lake Zwemlust $+2 \mathrm{mg} \mathrm{N}-\mathrm{NO}_{3} ;$ III, $+2 \mathrm{mg} \mathrm{N}-\mathrm{NH}_{4}$; and IV, $+2 \mathrm{mg} \mathrm{N}-\mathrm{NO}_{3}+2 \mathrm{mg} \mathrm{N}-\mathrm{NH}_{4}$.

Whitney test, $P \leq 0.01$ ). In the 14-days bioassay the plants absorbed about $50 \%$ and $75-90 \%$ of initial $\mathrm{P}$ and $\mathrm{N}$ content, respectively (Fig. 5).
Depending on $\mathrm{N}$ concentrations in the ambient medium $E$. nuttallii can utilize $1.3-1.6 \mathrm{mg} \mathrm{P} \mathrm{g}^{-1}$ DW and 0.1-9.0 $\mathrm{mg} \mathrm{N} \mathrm{g}^{-1} \mathrm{DW}$.

Elodea nuttallii depleted $\mathrm{N}$ in the water very rapidly. It preferred $\mathrm{N}-\mathrm{NH}_{4}$ to $\mathrm{N}-\mathrm{NO}_{3}$ if both ions were available in water in similar concentration (Fig. 6). A reduction of $50 \%$ of initial $\mathrm{N}-\mathrm{NH}_{4}$ content was noted after $8 \mathrm{~h}$. The plants absorbed almost all $\mathrm{N}-\mathrm{NH}_{4}$ in about $32 \mathrm{~h}$. The high uptake of $\mathrm{N}-\mathrm{NO}_{3}$ by plants began from $32 \mathrm{~h}$ when $\mathrm{N}-\mathrm{NH}_{4}$ was almost exhausted. After $64 \mathrm{~h}$ $75 \%$ of the $\mathrm{N}-\mathrm{NO}_{3}$ was taken up by plants. The plants assimilated only about $10 \%$ of $\mathrm{P}$ during the experiment lasting $64 \mathrm{~h}$ (Fig. 6).

\section{Discussion}

An important aim of the biomanipulation strategy to restore lakes has been to improve the underwater light climate in the lakes, with zooplankton reducing the seston, including algae, while 


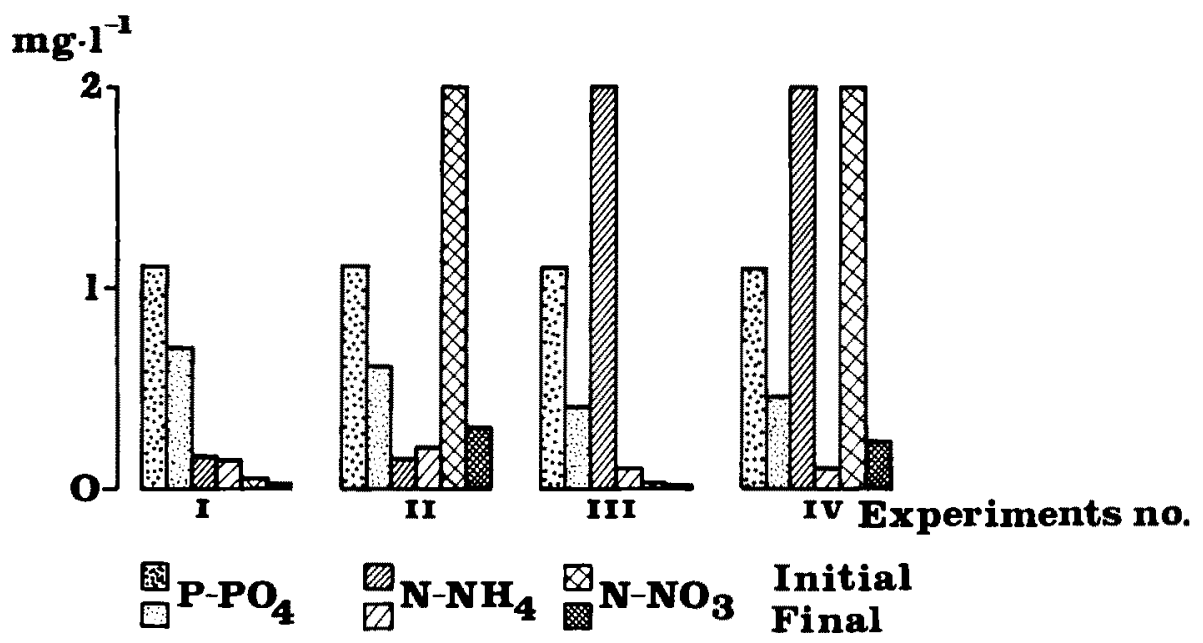

Fig. 5. Changes in the concentrations of $\mathrm{N}-\mathrm{NH}_{4}, \mathrm{~N}-\mathrm{NO}_{3}$ and $\mathrm{P}_{-} \mathrm{PO}_{4}$ in the medium after 14 days of cultivation E. nuttalli; codes as Figure 4.

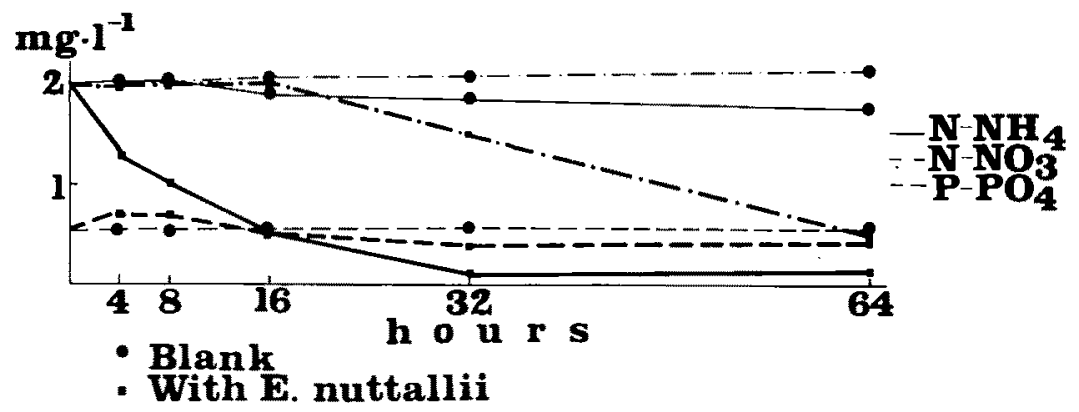

Fig. 6. Uptake rates of nitrogen and phosphorus of $E$. muttallii in water enriched with $2 \mathrm{mg} \mathrm{N}-\mathrm{NH}_{4}$ and $2 \mathrm{mg} \mathrm{N}-\mathrm{NO}_{3} ;$ solid circles, blanks; and solid squares, with E. nuttallii.

nutrient levels stay still high (Shapiro \& Wright, 1984; Lampert, 1988; Gulati, 1989). Light is considered to be a key factor regulating the growth and distribution of submerged macrophytes (Spence, 1972; Barko \& Smart, 1981; Barko \& Filbon, 1983). The biomanipulation approach should create conditions that stimulate growth of submerged macrophytes, particularly in spring when plants start to grow from the bottom.

In Lake Zwemlust, the response of submerged macrophytes to improving light climate was rapid. The course of changes in vegetation, namely from macrophytes and filamentous algae in 1986 (i.e. year before biomanipulation) to 1989 , is shown schematically in Fig. 7 . In 1987, in the first summer after biomanipulation, besides the species introduced, 5 species of submerged macrophytes occurred and had colonized $10 \%$ of the lake area (Van Donk et al., 1989). In 1988 only quantitative changes were observed; no more new species appeared, but the area colonized by the macrophytes increased 7 times compared with 1987 . The areal biomass increased to a level similar to that in eutrophic lakes, e.g. in many Polish eutrophic lakes (Pieczynska \& Ozimek, 1976). In 1989 the area occupied by macrophytes increased further such that virtually the entire lake bottom was covered, and the macrophyte biomass increased to a level, prevalent in fertile ponds (Pokorny \& Ondok, 1982) and lake habitats fertilized by municipal sewage (Ozimek, 1978). The importance of submerged macrophytes in ecosystem functioning is reported to be proportional to their biomass and productivity 


\section{BIOMANIPULATION}

(March 1987)
1986

- Phytoplankton predominant

- Water transparency low

- Macrophytes absent
SPRING 1987

- High zooplankton grazing

- Increased water clarity

\section{SUMMER 1987}

- Appearance of macrophytes and fil. green algae<smiles>C=CC</smiles>

SPRING 1988

- "Clear water" - resulting from zooplankton grazing

Chronology of limnological events in Lake Zwemlust (1987-1989)

\section{SUMMER 1989}

- Situation comparable with summer 1988 - a further $50 \%$ increase in macrophytes<smiles>[3H][3H]</smiles>

\section{SUMMER 1988}

- Predominance of macrophytes

- Subdominance fil. green algae

- Zooplankton grazing pressure moderate

- Improved underwater light climate

- High P, low N

Suppression of phytoplankton due to $\mathrm{N}$-limitation and shading and allelopathy (?) caused by macrophytes

\section{SPRING 1989}

- High water clarity, high P

- Grazing pressure moderate

Fig. 7. Scheme illustrating changes in macrophytes in Lake Zwemlust in 1986-1989.

(Carpenter \& Lodge, 1986). In this respect $E$. nuttallii has apparently played a central role in Lake Zwemlust, especially in view of the aim of the biomanipulation measures. E. nuttallii started growing actively very early in the year when water temperature is about $4{ }^{\circ} \mathrm{C}$, even though it is known to grow more intensively at temperatures between 10 and $17^{\circ} \mathrm{C}$ (Kuni, 1982). Possibly, an early canopy growth (Barko \& Smart, 1981;
Moss, 1990) of E. nuttallii, the dominant species in the lake, enables this species to successfully compete with other macrophytes, but also with filamentous algae and phytoplankton. Similarly, a positive effect of biomanipulation on submerged macrophytes was noted also in other Dutch lakes, e.g. in Lake Bleiswijkse Zoom (Meijer et al., 1989).

In Lake Zwemlust, together with macrophytes, 
filamentous green algae occurred in large amounts. Some workers have reported filamentous green algae to negatively affect the growth of some species of submerged macrophytes, e.g. E. canadensis (Simpson \& Eaton, 1986) and to cause their decline (Phillips et al., 1978). It remains to be seen if further developments in Lake Zwemlust will be commensurate with the hypothesis proposed by Phillips et al. (1978).

Macrophytes often accumulate large quantities of inorganic nutrients early in the growing season (Boyd, 1971). Nutrients stored during early spring growth are utilized for growth later. So, macrophytes which start to grow early in the season have a competitive advantage over other macrophyte species and phytoplankton. Dense stands of macrophytes can cause deficiencies of nutrient in water (Boyd, 1971). Such a situation was observed in Lake Zwemlust. Rapid growth and high biomass of plants caused limiation of $N$ in summers of 1988 and 1989 , but not of $P$, the level of which remained high (Van Donk et al., 1989; Van Donk et al., 1990). An important question about the role of macrophytes in lakes is the extent to which macrophytes beds act as source or sink for a nutrient. Generally, macrophyte stands always act as sink for dissolved N (Mickle \& Wetzel, 1978; Howard-Williams, 1981); as regards dissolved $P$, the macrophytes may act as a sink usually in spring but also sometimes as a source usually in summer (Prentki et al., 1978; Landers, 1982). In Lake Zwemlust in summers of 1988 and 1989 dense stands of macrophytes acted as sink for both $\mathrm{N}$ and $\mathrm{P}$. Our bioassay experiments supported $\mathrm{N}$ limitation by plants in the lake; this may explain inhibition of phytoplankton and periphyton growth (see e.g. Fitzgerald, 1968) both of which had very low biomass in 1988 and 1989. So, the persistence of clear water in 1988 and 1989 was probably caused by macrophytes, unlike in 1987 when zooplankton grazing contributed chiefly to water clarity (Gulati, 1989).

Macrophytes can affect phytoplankton not only by competing for nutrients but also by shading (Goulder, 1969) and, possibly, by allelopathy (Wium-Andersen et al., 1982). Role of macro- phytes in biomanipulation of lakes should be based not only on their negative effects on phytoplankton but also on their positive effects on zooplankton and fish. In deep lakes zooplankton has refuges against fish predation in deeper layers of lakes, but in shallow lakes plants may take over this role of 'sheltering' zooplankton. Species and size composition of fish in shallow lakes is associated with type and abundance of vegetation (Grimm, 1989; Engel, 1988). Engel (1988) reported that plant beds denser than $300 \mathrm{~g} \mathrm{DW}$ $\mathrm{m}^{-2}$ are difficult for fish to penetrate. In Lake Zwemlust macrophytes attained such high levels of biomass in many parts, despite the macrophyte removal by harvesting in early July 1989 . Water within the dense beds of macorphytes may become deoxygenated to a level deleterious to fish (Davis, 1975). Therefore, such situations should be prevented by control measures. Macrophytes create not only refuges but also foraging environment for fish. For example, macrophytes comprise a significant portion of diet of rudd (Prejs, 1984) which was common in Lake Zwemlust in 1988 and 1989.

In evaluating the role of aquatic plants in lake restoration their important features are: early active growth at low temperature, temperate productivity levels, high capacity for absorption of minerals and nutrients, mainly directly from water, storage of accumulated nutrients for long periods (overwintering plants), low $P$ release rates and a likely release of allelopathic substances which negatively affect phytoplankton growth. Besides, the macrophyte standing crop can be regulated by repeated harvesting during their extended growth period.

\section{Acknowledgements}

The first author feels indebted to the Limnological Institute, for providing funds for travel to The Netherlands and stay at the Vijverhof Laboratory of the Institute. Special thanks are due to Klaas Siewertsen, who did the chemical analyses of plants and Cecilia Janssen-Kroon for typing the manuscript. 


\section{References}

Barko, J. W. \& G. J. Filbin, 1983. Influences of light and temperature on chlorophyll composition in submersed freshwater macrophytes. Aquat. Bot. 15: 249-255.

Barko, J. W. \& R. M. Smart, 1981. Comparative influences of light and temperature on the growht and metabolism of selected submersed freshwater macrophytes. Ecol. Monogr. 51: 219-235.

Boyd, C. E., 1971. The limnological role of aquatic macrophytes and their relationship to reservoir management. Res. Fish Limnol. 8: 153-166.

Carpenter, S. R. \& D. M. Lodge, 1986. Effects of submerged macrophytes on ecosystem processes. Aquat. Bot. 26: 341-370.

Davis, J. C., 1975. Minimal dissolved oxygen requirements of aquatic life with emphasis on Canadian species: a review. J. Fish Res. Bd Can. 32: 2295-2332..

Engel, S., 1988. The role and interactions of submerged macrophytes in a shallow Wisconsin Lake. J. Freshwat. Ecol. 4: 229-341.

Fitzgerald, G. P., 1969. Some factors in the competition or antagonism among bacteria, algae, and aquatic weeds. J. Phycol. 5: $351-359$.

Golterman, H. L., 1969. Methods for chemical analysis of freshwaters. IBP Handbook 8, Blackwell Scientific Publications, Oxford, $166 \mathrm{pp}$.

Goulder, R., 1969. Interactions between the rates of productions of a freshwater macrophyte and phytoplankton in a pond. Oikos 20:300-309.

Grimm, M.P., 1989. Northern pike (Esox lucius L.) and aquatic vegetation, tools in the management of fisheries and water quality in shallow waters. Hydrobiol. Bull. 23: 59-65.

Gulati, R. D., 1989. Structure and feeding activities of zooplankton community in Lake Zwemlust, in the two vears after biomanipulation. Hydrobiol. Bull. 23: 35-48.

Howard-Williams, C., 1981. Studies on the ability of a Potamogeton pectinatus community to remove dissolved nitrogen and phosphorus compounds from water. J. appl. Ecol. 18: 619-637.

Kuni, H., 1982. The critical water temperature for the active growth of Elodea nuttalli (Planch.) St. John. Jap. J. Ecol. 32: $111-112$.

Lachavanne, J. B., 1985. The influence of accelerated eutrophication on the macrophytes of Swiss lakes: abundance and distribution. Verh. int. Ver. Limnol. 22: 2950-2955.

Landers, D. H., 1982. Effects of naturally senescing aquatic macrophytes on nutrient chemistry and chlorophyll $a$ of surrounding waters. Limnol. Oceanogr. 27: 428-439.

Lampert, W., 1988. The relation between zooplankton biomass and grazing. A review. Limnologica 19: 11-20.

Meijer, M. L., A. J. P. Raat \& E. W. Doef, 1989. Restoration by biomanipulation of Lake Bleiswijkse Zoom (The Netherlands): first results. Hydrobiol. Bull. 23: 49-57.

Mickle, A. M. \& R. G. Wetzel, 1978. Effectiveness of submersed angiosperm-epiphyte complexes on exchange of nutrients and organic carbon in littoral systems. Aquat. Bot. 4: 303-329.
Moss, B., (1990). Engineering and biological approaches to the restoration from eutrophication of shallow lakes in which aquatic plant communities are important components. Hydrobiologia 200/201: 367-377.

Murphy, J. \& J. P. Riley, 1962. A modified single solution method for determination of phosphate in natural waters. Analyt. chim. Acta 26: 31-36.

Ozimek, T., 1978. Effects of municipal sewage on the submerged macrophytes of lake littoral. Ekol. pol. 26: 1-39.

Ozimek, T. \& A. Kowalczewski, 1984. Long-term changes of the submerged macrophytes in eutrophic Lake Mikolajskie (North Poland). Aquat. Bot. 19: 1-11.

Phillips, G. L., D. Eminson \& B. Moss, 1978. A mechanism to account for macrophyte decline in progressively eutrophicated freshwaters. Aquat. Bot. 4: 103-126.

Pieczynska, E. \& T. Ozimek, 1976. Ecological significance of lake macrophytes. Int. J. Ecol. Envir. Sci. 2: 115-128.

Pokorny \& Ondok, 1982. Photosynthesis and primary production in submerged macrophyte stands. In: B. Gopal, R. E. Turner, R. G. Wetzel \& D. E. Whigham (eds). Wetlands: Ecology and management, Internat. Sci. Publ. Jaipur, India: 206-214.

Prejs, A., 1984. Herbivory by temperature freshwater fishes and its consequences. Envir. Biol. Fishes 10: 281-296.

Prenki, R. T., T. D. Gustafson \& M. S. Adams, 1978. Nutrient movements in lakeshore marshes. In: R. E. Good, D. F. Zhigham \& R. L. Simpson (eds). Freshwater Wetlands. Academic Press, New York, London: 169-194.

Shapiro, J. \& D. I. Wright, 1984. Lake restoration by biomanipulation: Round lake Minnesota, the first two years. Freshwat. Biol. 14: 371-383.

Simpson, P. S. \& J. W. Eaton, 1986. Comparative studies of photosynthesis of the submerged macrophyte Elodea canadensis and filamentous algae Cladophora glomerata and Spirogyra sp. Aquat. Bot. 14: 1-22.

Spence, D. H. N., 1972. Light on freshwater macrophytes. Botanical Society of Edinburgh Transactions, 41: 491-505.

Stainton, M. P., M. J. Capel \& P. J. Armstrong, 1974. The chemical analysis of freshwater. Miscellaneous special publications no. 25. Research and Development Directorate Freshwater Institute, Winnipeg, Manitoba.

Van Donk, E., in press. Changes in community structure and growth limitation of phytoplankton due to top-down foodweb manipulation. Verh. int. Ver. Limnol. 24.

Van Donk, E, R. D. Gulati \& M. P. Grimm, 1989. Food-web manipulation in Lake Zwemlust: positive and negative effects during the first two years. Hydrobiol. Bull. 23: 19-34.

Van Donk, E., M. P. Grimm, R. D. Gulati \& J.P. G. Klein-Breteler (1990). Whole-lake food-web manipulation as a means to study community interactions in a small ecosystem. Hydrobiologia 200/201: 275-289.

Verdouw, H., C. J. A. Echteld \& E. M. J. Dekkers, 1977. Ammonia determination based on indophenol formation with sodium salicylate. Wat. Res. 12: 399-402.

Wium-Andersen, S. U., U. Anthoni, C. Cristophersen \& G. Houen, 1982. Allepathic effects on phytoplankton by substances isolated from aquatic macrophytes (Charales). Oikos 39: 187-190. 